University of South Carolina

Scholar Commons

$12-14-2012$

\title{
High Performance Low Temperature Solid Oxide Fuel Cells with Novel Electrode Architecture
}

Yu Chen

Qian Liu

Zhibin Yang

Fanglin Chen

University of South Carolina - Columbia, chenfa@cec.sc.edu

Minfang Han

Follow this and additional works at: https://scholarcommons.sc.edu/emec_facpub

Part of the Applied Mechanics Commons, Electro-Mechanical Systems Commons, Materials Science and Engineering Commons, and the Other Mechanical Engineering Commons

\section{Publication Info}

Published in RSC Advances, Volume 21, Issue 32, 2012, pages 12118-12121.

CRSC Advances 2012, Royal Society of Chemistry.

This article cannot be redistributed or further made available. This article was first published by the Royal Society of Chemistry and can be found at http://dx.doi.org/10.1039/C2RA21921B

Chen, Y., Liu, Q., Yang, Z., Chen, F. \& Han, M. (14 December 2012). High Performance Low Temperature Solid Oxide Fuel Cells with Novel Electrode Architecture. RSC Advances, 2 (32), 12118 - 12121.

http://dx.doi.org/10.1039/C2RA21921B

This Article is brought to you by the Mechanical Engineering, Department of at Scholar Commons. It has been accepted for inclusion in Faculty Publications by an authorized administrator of Scholar Commons. For more information, please contact digres@mailbox.sc.edu. 


\title{
RSC Advances
}

\section{High performance low temperature solid oxide fuel cells with novel electrode architecture}

\author{
Yu Chen, ${ }^{a}$ Qiang Liu, $\dagger^{a}$ Zhibin Yang, ${ }^{a b}$ Fanglin Chen ${ }^{* a}$ and Minfang Han*b \\ Received 24th August 2012, Accepted 4th October 2012 \\ DOI: 10.1039/c2ra21921b
}

In this study, we have fabricated high performance low temperature solid oxide fuel cells (LT-SOFCs) with both acicular anodes and cathodes with thin Gd-doped ceria (GDC) electrolyte film. The acicular $\mathrm{Ni}-\mathrm{Gd}_{0.1} \mathrm{Ce}_{0.9} \mathrm{O}_{2-\delta}$ (Ni-GDC) anode was prepared using freeze drying tape casting, while the hierarchically porous cathode with nano-size $\mathrm{Sm}_{0.5} \mathrm{Sr}_{0.5} \mathrm{CoO}_{3}$ (SSC) particles covering an acicular GDC skeleton was prepared by a combination of freeze drying tape casting and self-rising approaches. The acicular electrodes with 5-200 $\boldsymbol{\mu m}$ pores/channels enhance mass transport, while SSC particles of about $50 \mathrm{~nm}$ in the cathode promote electrochemical reactions. Cells which have this novel electrode architecture show a significantly high power output of $1.44 \mathrm{~W} \mathrm{~cm}^{-2}$ and an extremely low cell polarization resistance of $0.0379 \Omega \mathrm{cm}^{2}$ at $600{ }^{\circ} \mathrm{C}$.

The solid oxide fuel cell (SOFC) is one of the most promising techniques for next generation power systems due to its high efficiency and low emissions. ${ }^{1}$ However, the high cost of current SOFC systems is hindering wide-spread commercial applications. The cost can be dramatically reduced by decreasing the SOFC operating temperature to $400-600{ }^{\circ} \mathrm{C}$, which would expand the choice of materials and stack configurations and reduce the corrosion rate of the stack and system components. ${ }^{2}$ Two key obstacles to achieving high performance LT-SOFC are the high cell ohmic resistance and polarization resistance. Lowering cell ohmic resistance has been achieved through the application of a thin electrolyte with high ionic conductivity in this study. Ceria based compound, such as GDC $\left(\mathrm{Gd}_{0.1} \mathrm{Ce}_{0.9} \mathrm{O}_{2-\delta}\right)$, have been regarded as the most promising electrolyte for LT-SOFCs, due to its much higher ionic conductivity (about $0.025 \mathrm{~S} \mathrm{~cm}^{-1}$ at $600{ }^{\circ} \mathrm{C}^{3}$ ) compared to that of yttria stabilized zirconia (YSZ). However, the GDC electrolyte film fabrication process is often complicated and expensive, limiting the development of LT-SOFC. ${ }^{4,5}$ For more economical fabrication of dense GDC film, we are applying a simple and cost effective dropcoating and co-firing method. In this process, an acicular anode supported cell with GDC dense electrolyte film and a GDC skeleton

${ }^{a}$ Department of Mechanical Engineering, University of South Carolina, Columbia, SC,29205,USA. E-mail: chenfa@cec.sc.edu

${ }^{b}$ Union Research Center of Fuel Cell, School of Chemical Engineering,

China University of Mining \& Technology, Beijing, 10083, China.

E-mail: hanminfang@sina.com

$\uparrow$ Current address: Cummins Emissions Solutions, 525 Jackson Street, Columbus, IN 47201, USA can be formed in a single co-firing step. In order to reduce the cell polarization resistance, we have applied novel electrode architecture to enhance the cell performance. Tailoring the microstructure to enlarge the length of triple phase boundary (TPB, where gas, electronic-conducting phase and ionic-conducting phase meet) is a commonly applied strategy in the fabrication of high performance electrodes. It has been reported that nano-sized oxides have enhanced catalytic properties due to their increased surface active sites and effective conductivities. ${ }^{6-10}$ Furthermore, both experimental results and the modelling studies have indicated that a nanostructured electrode is an ideal microstructure, taking the advantages of both high electro-catalytic activity and extended TPB length. ${ }^{11-17}$ The commonly used technique to prepare nano-structured electrodes is infiltration/impregnation, ${ }^{18,19}$ which allows the formation of nanoparticles and the desirable catalyst phase at a much lower firing temperature than the traditional fabrication process. For example, in the mechanical mixing process, a $\mathrm{Sm}_{0.5} \mathrm{Sr}_{0.5} \mathrm{CoO}_{3}$-GDC (SSC-GDC) composite cathode is often prepared at $1000{ }^{\circ} \mathrm{C}$ for $4 \mathrm{~h},{ }^{20}$ whereas in the infiltration process, $800{ }^{\circ} \mathrm{C}$ for $1 \mathrm{~h}$ is adequate for the deposition of SSC nano-particles on the Sm-doped ceria (SDC) backbone. ${ }^{21}$ The characteristics of the nano-particles can be preserved at low cell operating temperature, which is beneficial for the maintenance of high catalytic activity and extended TPB length.

The self-rising approach, which is an extension of the combustion synthesis method, has recently been developed in our group for the preparation of nano-crystal aggregates for SOFCs. ${ }^{10,22}$ Organic materials such as P123 and urea have been used as fuel, which generates heat and large amount of gases to form extremely loose nano-crystals with high BET (Brunauer-Emmett-Teller) surface area during the combustion process. However, the solution for the selfrising process is much thicker (due to the presence of P123 surfactant) than for the traditional infiltration/impregnation process. Moreover, the electrode skeleton prepared by screen-printing and subsequent firing of a ceramic ink is not suitable for infiltration/ impregnation by the self-rising solution, due to the low porosity and high tortuosity of the electrode skeleton and the high viscosity of the self-rising solution. In addition, the screen-printed skeleton would be broken by the formation of large amounts of gases during heating up of the self-rising solution. Recently, a novel freeze drying tape casting process has been developed to fabricate acicular electrodes in solid oxide fuel cells. ${ }^{23-25}$ Continuously graded acicular pores/channels with micron-scale pore sizes can be achieved through this technique, which are very useful for gas delivery in the electrodes. The electrode 
pores/channels can even be preserved after calcination at $1450{ }^{\circ} \mathrm{C}$. The thick solution from the self-rising approach can readily pass through the acicular macro pores/channels without the requirement of vacuum in the infiltration/impregnation process.

Here, we report a high performance LT-SOFC possessing a novel electrode architecture with an acicular Ni-GDC anode, prepared using freeze drying tape casting, and a hierarchically porous cathode, comprised of nano SSC particles covering an acicular GDC skeleton ,prepared by freeze drying tape casting and self-rising approaches. Button single cells, consisting of an acicular NiO-GDC $(6: 4$ in mass ratio) as the anode, thin GDC film as the electrolyte and an acicular GDC skeleton covered by nano SSC particles as the composite cathode, have produced a power density of $1.44 \mathrm{~W} \mathrm{~cm}^{-2}$ at $600{ }^{\circ} \mathrm{C}$, the highest cell power output produced by such materials. The acicular anode and cathode facilitate fuel and oxidant delivery in both electrodes and the nano SSC particles accelerate electrochemical reactions in the cathode.

Water based NiO-GDC and GDC slurry with solid loading of 25 $\mathrm{vol}^{2} \%$ and $15 \mathrm{vol} \%$, respectively, were prepared with an ammonium polyacrylate dispersant (Darvan C-N, R.T. Vanderbilt Co., Inc., Norwalk, CT), a thickener (Vanzan, R.t. Vanderbit Co., Inc., Norwalk, CT), and an acrylic latex emulsion binder system (Durmax HA-12, Rohm \&Hass, Philadelphia, PA). NiO and GDC powders were weighed out in a ratio of $6: 4$ and then mixed with distilled water, Darvan and Vanzan in a plastic bottle using a planetary centrifugal mixer (Thinky mixer, ARE-310). The solid loading was controlled at $25 \mathrm{vol} \%$. The bottle was then sealed and heated in an oven at $80^{\circ} \mathrm{C}$ for $1 \mathrm{~h}$. The mixing-heating cycle was repeated 4 times before the slurry was ready to cast. Details of substrate preparation can be found in our previous report. ${ }^{25}$ The GDC electrolyte slurry was directly deposited on the green NiO-GDC substrate by dropcoating. GDC substrate was then laminated onto the GDC green film surface. The NiO-GDC anode/GDC electrolyte film/GDC cathode skeleton tri-layers were then co-fired at $1450{ }^{\circ} \mathrm{C}$ for $12 \mathrm{~h}$, with a heating rate of $1{ }^{\circ} \mathrm{C} \mathrm{min}^{-1}$ until the temperature reached 600 ${ }^{\circ} \mathrm{C}$ and at $2{ }^{\circ} \mathrm{C} \mathrm{min}^{-1}$ after this. Details of the SSC solution for selfrising can be found in our previous study. ${ }^{26}$ The cathode was prepared by dropping SSC solution into GDC skeleton, followed by drying in an oven at $80{ }^{\circ} \mathrm{C}$ for $10 \mathrm{~h}$ and then firing at $800{ }^{\circ} \mathrm{C}$ for $2 \mathrm{~h}$. This cycle was repeated 5-6 times until the mass ratio of SSC and GDC was about $1: 1$. The SSC loading level can be determined by measuring the weight difference after each cycle. For convenience, the cell with acicular Ni-GDC anode and nano structured SSC prepared by self-rising was denoted as Cell-SR. For comparison, an acicular Ni-GDC supported cell with GDC thin film prepared by drop-coating and traditional SSC-GDC composite cathode prepared by screen-printing (denoted as Cell-SP) and a traditional porous $\mathrm{Ni}$ GDC anode supported cell with GDC thin film fabricated by copressing the anode/electrolyte and SSC-GDC cathode fabricated by screen-printing (denoted as Cell-CP) have also been prepared and evaluated. SSC powders were prepared by a citric acid assisted combustion method. ${ }^{27}$

The microstructure of the cells was characterized using a scanning electron microscope (SEM, Zeiss Ultra plus FESEM). Fig. 1 (a) shows the SEM images of the as-prepared single cell after electrochemical performance measurement. The cell has a thick acicular Ni-GDC anode layer, a thin dense GDC electrolyte layer and a thick acicular SSC-GDC layer with thicknesses of about 600 , 30 and $200 \mu \mathrm{m}$, respectively. The dense GDC electrolyte is well

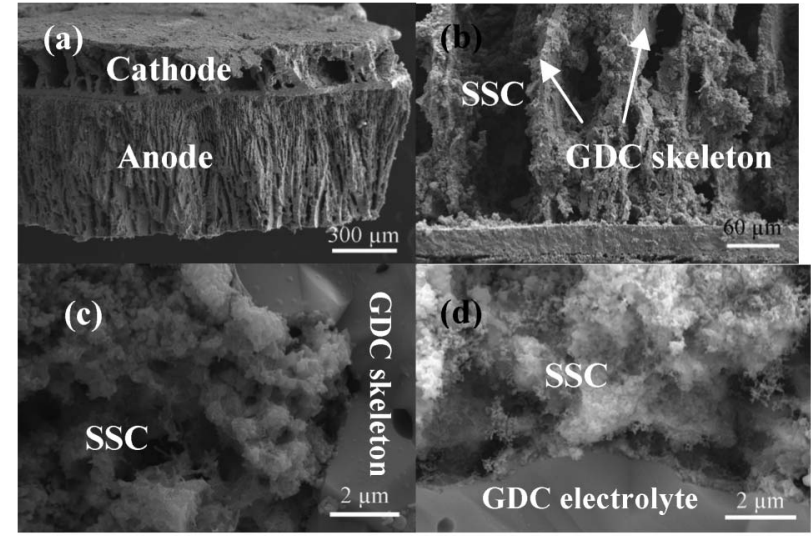

Fig. 1 SEM images of a single cell with nano structured SSC (a), its cathode and electrolyte (b), the bulk of the cathode (c) and the cathode area adjacent to the electrolyte (d).

adhered to the electrodes. Fig. 1(b) shows a magnified image of the cathode and electrolyte. Fig. 1(c) and(d) show images of the cathode area in the bulk of the cathode and adjacent to the electrolyte, respectively. It can be seen that nano SSC particles in these areas display foam-like morphology and attach to the GDC skeleton or the electrolyte very well. The presence of acicular pores in the electrodes will facilitate mass transport to the TPB area, which will decrease concentration resistance. ${ }^{17,25}$ Moreover, TPB length will be significantly extended by the covering of nano SSC particles on the GDC cathode backbone and the electrolyte, thus accelerating electrochemical reactions and decreasing the activation resistance. ${ }^{18}$

The current density-voltage $(I-V)$ curves, as well as the impedance spectra, of the cells were measured by a four probe method using a multi-channel Versa STAT (Princeton Applied Research) at an operating temperature range of $500-600{ }^{\circ} \mathrm{C}$. Humidified (3 vol\% $\mathrm{H}_{2} \mathrm{O}$ ) hydrogen was used as the fuel while ambient air was used as the oxidant. Hydrogen flow rate was controlled at $40 \mathrm{sccm}$ (standard cubic centimetres per minute) by a mass flow controller (APEX, Alicat Scientific). Fig. 2(a) shows the cell voltage (V), current $(I)$ and power $(P)$ density curves of the cell with a nano-structured SSC cathode (Cell-SR) using hydrogen as fuel and ambient air as oxidant at different operating temperatures. The open circuit voltages (OCV) of the cell are $0.923,0.900$ and $0.868 \mathrm{~V}$ at 500,550 and $600{ }^{\circ} \mathrm{C}$, respectively. These are lower than the cell Nernst potential, which can be attributed to the minor electronic conduction of the GDC electrolyte due to the reduction of $\mathrm{Ce}^{4+}$ in the reducing atmosphere. ${ }^{28}$ These $\mathrm{OCV}$ values are in good agreement with the $\mathrm{OCV}$ values of the ceria-based electrolyte reported by others. ${ }^{17,20}$ The maximum cell power densities are $0.522,0.923$ and $1.44 \mathrm{~W} \mathrm{~cm}^{-2}$ at 500,550 and $600{ }^{\circ} \mathrm{C}$, respectively. The cell power output is much higher than the two best performance LT-SOFCs previously reported for SSC or SSC-SDC composite cathodes, in which peak cell power densities of $440 \mathrm{~mW} \mathrm{~cm}{ }^{-2}$ and $476 \mathrm{~mW} \mathrm{~cm}^{-2}$ at $500{ }^{\circ} \mathrm{C}$ were obtained for cells with similar electrode and electrolyte materials. ${ }^{13,29}$ It is worth mentioning that the thickness of the electrolyte in these two previous reports is around $10 \mu \mathrm{m}$, while it was about $30 \mu \mathrm{m}$ in the present work, further demonstrating the advantages of the electrode architecture achieved in this study. The enhancement of cell power output in this work can be attributed to the novel acicular electrode microstructures and the nano-sized SSC catalyst. Fig. 2(b) shows 


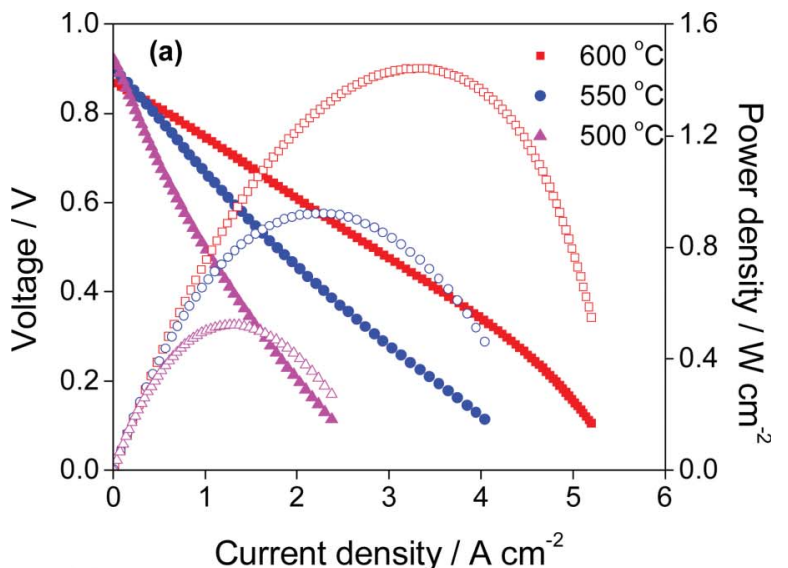

(b)
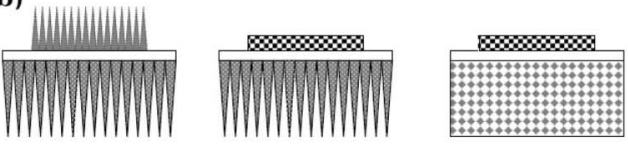

Cell-SR

Cell-SP

Cell-CP

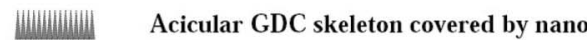
SSC

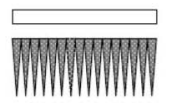

GDC electrolyte

180080

Acicular Ni-GDC anode

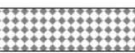

Traditional SSC-GDC cathode

Traditional Ni-GDC anode

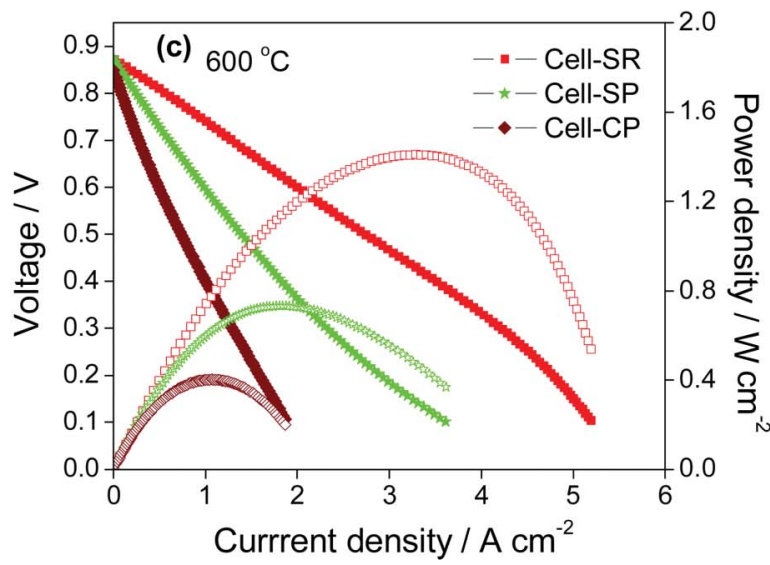

Fig. 2 (a) $I-V$ and $I-P$ curves of Cell-SR measured at different temperatures using hydrogen as fuel $(40 \mathrm{sccm})$ and ambient air as oxidant; (b) Schematic view of Cell-SR, Cell-SP and Cell-CP and (c) Comparison of $I-V$ and $I-P$ curves of Cell-SR, Cell-SP and Cell-CP measured at $600{ }^{\circ} \mathrm{C}$.

schematic views of the three types of cells (Cell-SR, Cell-SP and Cell$\mathrm{CP}$ ) with different electrode architectures. Both the anode and the cathode are conventionally sponge-like, porous microstructures in Cell-CP. For Cell-SP, the anode is acicular, while the cathode is a conventionally sponge-like microstructure. For Cell-SR, both the anode and cathode are acicular, which is expected to significantly facilitate mass transport. As shown in Fig. 2(c), Cell-SP and Cell-CP only produce a cell power output of 0.732 and $0.402 \mathrm{~W} \mathrm{~cm}^{-2}$ at 600 ${ }^{\circ} \mathrm{C}$, respectively, under similar testing conditions. In addition, the cell power output of Cell-SP obtained in this study is higher than those
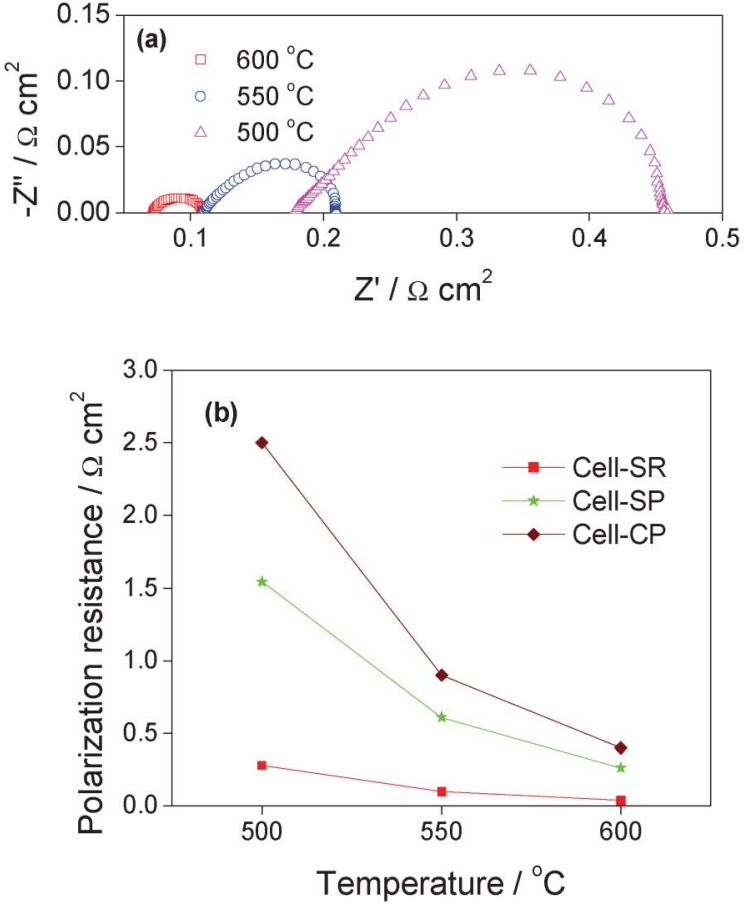

Fig. 3 (a) Impedance spectra of Cell-SR tested at different temperature under open circuit conditions and (b) comparison of polarization resistance of Cell-SR, Cell-SP and Cell-CP operated at different temperature.

reported by others in which the anode was composed of similar conventionally sponge-like microstructures and cell materials. ${ }^{22,29,30}$ Since the thicknesses of the electrolyte and cathode in Cell-SP and Cell-CP are similar, the significant increase in the cell power output in Cell-SP can be attributed to the acicular anode, in which both fuel and product transport can be facilitated.

Fig. 3(a) shows the impedance spectra of Cell-SR measured at different temperatures under open circuit conditions. The ohmic resistance $\left(R_{\mathrm{ohm}}\right)$, corresponding to the high frequency intercept of the impedance spectra with the real axis in the Nyquist plot, is $0.1784,0.1094$ and $0.0718 \Omega \mathrm{cm}^{2}$ at 500,550 and $600{ }^{\circ} \mathrm{C}$, respectively. Such a low ohmic resistance could be attributed to the increase in the effective working area due to the presence of nano SSC particles at the cathode/electrolyte interface. ${ }^{31}$ The polarization resistance $\left(R_{\mathrm{p}}\right)$ determined from the difference between the high and low frequency intercepts of the impedance spectra with the real axis is about 0.2802 , 0.1002 and $0.0379 \Omega \mathrm{cm}^{2}$ at 500,550 and $600{ }^{\circ} \mathrm{C}$, respectively. This $R_{\mathrm{p}}$ value is lower than our previous report for the nano network SSC-SDC cathode (a polarization resistance of about $0.052 \Omega \mathrm{cm}^{2}$ at $\left.600{ }^{\circ} \mathrm{C}\right),{ }^{13}$ which is the lowest value ever reported for a SSC cathode. Fig. 3(b) shows a comparison of $R_{\mathrm{p}}$ for Cell-SR, Cell-SP and Cell-CP at different operating temperatures. $R_{\mathrm{p}}$ of Cell-SR has been greatly decreased compared to that of Cell-SP and Cell-CP. For example, at $600{ }^{\circ} \mathrm{C}, R_{\mathrm{p}}$ of Cell-CP and Cell-SP is 0.3995 and $0.2628 \Omega \mathrm{cm}^{2}$, respectively, while $R_{\mathrm{p}}$ of Cell-SR is only $0.0379 \Omega \mathrm{cm}^{2}$. Considering that both the composition and microstructure of the cathode are identical, while the composition of the anode is also the same for Cell-SP and Cell-CP, the difference in cell polarization resistance may be attributed to the different anode microstructure. The acicular pores/channels in Cell-SP are helpful for gas delivery. Similarly, for Cell-SR and Cell-SP, due to the difficulty of separating anodic and 
cathodic polarization $\left(R_{\mathrm{a}}\right.$ and $R_{\mathrm{c}}$ ) from the total cell polarization resistance $\left(R_{\mathrm{p}}\right),{ }^{32}$ it is reasonable to consider that the change in $R_{\mathrm{p}}$ comes mainly from the cathode. The acicular GDC skeleton with macro channels facilitates oxygen diffusion and the nano-structured SSC catalyst with high BET surface area accelerates electrochemical reactions.

Employing electrodes with high porosity and low tortuosity leads to a low polarization resistance and consequently enhanced cell performance. ${ }^{17,25,33}$ For example, as reported by Suzuki, ${ }^{33}$ a cell with a conventionally sponge-like anode (pores size of about $2 \mu \mathrm{m}$ and porosity of as high as $54 \%$ ) showed a very high power density of over $1 \mathrm{~W} \mathrm{~cm}^{-2}$ and $R_{\mathrm{p}}$ of $0.1 \Omega \mathrm{cm}^{2}$ at $600{ }^{\circ} \mathrm{C}$, which can be attributed to the improvement in the anode microstructure. Othman et al. reported that a micro-tubular SOFC with finger-like pores demonstrated a high cell power output of $2.32 \mathrm{~W} \mathrm{~cm}^{-2}$ and a total cell polarization resistance, $R_{\mathrm{p}}$, of only $0.025 \Omega \mathrm{cm}^{2}$ at $600{ }^{\circ} \mathrm{C}$ when the finger-like pores occupied $70 \%$ of the anode thickness. ${ }^{17}$ These studies highlight the significance of electrode architecture in SOFC performance. The acicular electrode architecture obtained from freeze drying tape casting from this work has gradient straight open channels, beneficial to hydrogen or oxygen molecule diffusion to the electrode/electrolyte interface as well as water vapour diffusion away from the anode/electrolyte interface. Furthermore, the nanostructured SSC cathode catalyst obtained from the self-rising approach in this study can significantly enhance the cathode electrochemical performance.

In summary, a high performance LT-SOFC with novel electrode architecture consisting of an acicular Ni-GDC anode and an acicular GDC skeleton covered with nano SSC catalyst as the cathode has been successfully prepared by freeze drying tape casting and selfrising approaches. This single cell demonstrates a notably high cell power output and a significantly low cell polarization resistance. The presence of acicular pores in the electrodes facilitates mass transport while the nano SSC catalyst extends TPB length, thus accelerating electrochemical reactions in the cathode. The novel electrode architecture obtained in this study can be used for the development of other high performance electrochemical devices for various applications.

\section{Acknowledgements}

We're grateful to the financial support from National Science Foundation (0967166, 1000068 and 1210792) and the HeteroFoam Center, an Energy Frontier Research Center funded by the U.S. Department of Energy, Office of Science, Office of Basic Energy Sciences under Award Number DESC0001061

\section{References}

1 S. C. Singhal, Solid State Ionics, 2002, 152-153, 405-410.

2 D. J. L. Brett, A. Atkinson, N. P. Brandon and S. J. Skinner, Chem. Soc. Rev., 2008, 37, 1568-1578.

3 B. C. H. Steele, Solid State Ionics, 2000, 129, 95-110.

4 D. Ding, B. Liu, Z. Zhu, S. Zhou and C. Xia, Solid State Ionics, 2008, 179, 896-899.

5 R. Tian, F. Zhao, F. Chen and C. Xia, Solid State Ionics, 2011, 192, 580-583.

6 A. S. Arico, P. Bruce, B. Scrosati, J.-M. Tarascon and W. van Schalkwijk, Nat. Mater., 2005, 4, 366-377.

7 Z.-Y. Yuan, V. Idakiev, A. Vantomme, T. Tabakova, T.-Z. Ren and B.-L. Su, Catal. Today, 2008, 131, 203-210.

8 S. P. Jiang, S. Zhang, Y. D. Zhen and W. Wang, J. Am. Ceram. Soc, 2005, 88, 1779-1785.

9 T. Wu, Y. Zhao, R. Peng and C. Xia, Electrochim. Acta, 2009, 54, 4888-4892.

10 Q. Liu, F. Zhao, X. Dong, C. Yang and F. Chen, J. Phys. Chem. C, 2009, 113, 17262-17267.

11 Y. Chen, J. Bunch, C. Jin, C. Yang and F. Chen, J. Power Sources, 2012, 204, 40-45.

12 Y. Chen, F. Chen, W. Wang, D. Ding and J. Gao, J. Power Sources, 2011, 196, 4987-4991.

13 F. Zhao, Z. Wang, M. Liu, L. Zhang, C. Xia and F. Chen, J. Power Sources, 2008, 185, 13-18.

14 R. Tian, J. Fan, Y. Liu and C. Xia, J. Power Sources, 2008, 185, $1247-1251$.

15 D. Ding, W. Zhu, J. Gao and C. Xia, J. Power Sources, 2008, 179, 177-185.

16 G. Xiao and F. Chen, Electrochem. Commun., 2011, 13, 57-59.

17 M. H. D. Othman, N. Droushiotis, Z. Wu, G. Kelsall and K. Li, Adv. Mater., 2011, 23, 2480-2483.

18 Z. Jiang, C. Xia and F. Chen, Electrochim. Acta, 2010, 55, 3595-3605.

19 S. P. Jiang, Mater. Sci. Eng., A, 2006, 418, 199-210.

20 C. Xia, W. Rauch, F. Chen and M. Liu, Solid State Ionics, 2002, 149, $11-19$.

21 H. Zhang, F. Zhao, F. Chen and C. Xia, Solid State Ionics, 2011, 192, 591-594.

22 Q. Liu, X. Dong, C. Yang, S. Ma and F. Chen, J. Power Sources, 2010, 195, $1543-1550$

23 S. W. Sofie, J. Am. Ceram. Soc., 2007, 90, 2024-2031.

24 T. L. Cable and S. W. Sofie, J. Power Sources, 2007, 174, 221-227.

25 Y. Chen, J. Bunch, T. Li, Z. Mao and F. Chen, J. Power Sources, 2012, 213, 93-99.

26 Q. Liu and F. Chen, J. Nanosci. Nanotechnol., 2010, 10, 4317-4321.

27 G. Xiao, Q. Liu, X. Dong, K. Huang and F. Chen, J. Power Sources, 2010, 195, 8071-8074.

28 H. Inaba and H. Tagawa, Solid State Ionics, 1996, 83, 1-16.

29 L. Zhang, F. Chen and C. Xia, Int. J. Hydrogen Energy, 2010, 35, 13262-13270.

30 C. Xia and M. Liu, J. Am. Ceram. Soc., 2001, 84, 1903-1905.

31 F. P. F. van Berkel, F. H. van Heuveln and J. P. P. Huijsmans, Solid State Ionics, 1994, 72, Part2, 240-247.

32 S. McIntosh, J. M. Vohs and R. J. Gorte, J. Electrochem. Soc., 2003, 150, A1305-A1312.

33 T. Suzuki, Z. Hasan, Y. Funahashi, T. Yamaguchi, Y. Fujishiro and M. Awano, Science, 2009, 325, 852-855. 